\title{
Phenomenon of Injustice in Profit Sharing Ratio of Indonesia Islamic Banks' Mudarabah Contract
}

\author{
Kumara Adji Kusuma \\ Universitas Muhammadiyah Sidoarjo, \\ Sidoarjo, Indonesia \\ adji@umsida.ac.id
}

\begin{abstract}
This paper aims to find out the phenomenon of injustice experienced by Islamic banks consumers in dealing with the profit sharing ratio of the mudarabah contract. The method opted for an exploratory study using the phenomenological approach which covers consumers of Indonesia Islamic banks. The data were triangulated and complemented by documentary analysis, official website resources, and annual reports of the banks. In the findings, the paper provides empirical data about the consumers' familiarity of unfairness in the profit sharing ratio of the partnership contract of Indonesia Islamic banks based on interview with the banks' consumers. The consumers feeling of injustice occurred when the Islamic banks did not perform the execution of the mudarabah contract strictly to its requirements which based on Islamic jurisprudence. Other findings, there are gaps between the conventional and Islamic banks in terms of pricing standardization and also within the Islamic banks themselves in determining the profit sharing ratio which then create the injustice in the mudarabah contract. The finding of these phenomena would inform the policy maker and banks' manager to regulate a juster profit sharing ratio.
\end{abstract}

Keywords-fairness; partnership; agreement; negotiation; Islam; Bank; Indonesia

\section{INTRODUCTION}

Since its inception in 1992, until now, Islamic Banking in Indonesia has grown and developed rapidly. Muslim society has also began to recognize the various products of Islamic financial institutions (IFI). In terms of funding and financing, there are two main banking products namely the products using sale (bay) contract and the products using partnership (shirkah) contract. In the partnership contract there are two types of contract used i.e. Musharakah (venture capital) and Mudarabah (silent partnership) contract [1]. This paper focuses in the mudarabah agreement where one as capitalist and the other as entrepreneur who manage the capital. The consumers in both functions, the funding and financing, felt the unfairness when come to the profit sharing ratio, the ratio which predetermined the portion of profit to be shared should the business incurred profit in the business concluded.

There are researches which focuses on Islamic banks customer satisfactions have been conducted. A research by
Mohamed Sharif Bashir [2] finds indirect effects of Islamic bank's service quality and product quality on Brunei Darussalam's Islamic bank customer satisfaction awareness which revealed were positive and significant. The respondents know and understand what are the products and the services of Islmic banks up to certain level. Besides, the customers choose the Islamic bank because of its profitability and religious doctrines. Other researcher, Sameena Begum [3] obeserved the the motives of the customers in Oman in choosing between the Islamic bank or the conventional bank. Sameena Begum finds They felt satisfied by the facilities given by the banks with their own different motives. Other researchers in Pakistan [4] [5] analyze the releationship of service quality, customer satisfaction, dan bank performance. The research is conducted using comparison method between the Islamic and conventional banks. They found that Islamic banks are more popular because of its riba free producst, activities of risk sharing and strong relation with the religion, works as welfare organisation which promoting trade and economic activities which in accordance with doctrine of Islam. A research on customer satisfaction of Islamic banks in Malaysia [6] studied the consuymers' criteria in selecting a conventional bank that has an Islamic System. By using CARTER model. It also pinpoint the service quality and customer satisfaction among the fully fledged Islamic banks and the conventional banks which offering Islamic banking products and services. In Turkey, there's a research conducted by H. Şaduman Okumuş who investigates Islamic banks customer satisfaction [7]. This paper tries to evaluate the level of customer awareness and satisfaction with Islamic banking. The respondents revealed their discontent with some of the bank products and services like the partnership such as mudarabah and musharakah. They informed that they are not dealing with these type of contracts. Deasy Wulandaria and Ari Subagio [8] described customer decision-making perception of the differences in the quality of services between Islamic and conventional banking. The customers choose an bank to get a low administrative fee and a friendly service. But, they lack of understanding on revenue sharing provided by the bank since they consider it as the same as riba. Besides, the customer choose a bank for the wide range of its branch offices and the ATMs.

Based on all of the studies mentioned above, all of the reseachers mentioned the level of customer satisfaction on islamic banks product with its details in many countries which has Islamic banks in its banking system, be it in single 
banking system or dual banking system that accomodates islamic bank opoeration. Most of the researches mentioning the preference of islamic bank customer and analyse to know the customer level of satisfaction which means that which banks satisfied the customer more by providing the facilities. However there are not any research which indicates the customer experience on phenomenon of injustice in profit sharing ratio of Indonesia Islamic Banks' mudarabah contract been done. This paper focuses on this topic which then fill up the research gap in the Islamic banking body of knowledge. The exposition will alarm the government and practioners of islamic on the injustice being exposed to the practice of Islamic bank in Indonesia.

\section{Methodology}

This research uses qualitative method of phenomenology. This method is based on the experience of people on a certain phenomenon that happened at a certain time and at a location. Phenomenological approach pursues to comprehend the meaning of occasions and connection to ordinary individuals of groups in certain circumstances [9].

The study aims to portray and comprehend the experiences of people, including interactions with other people of a particular phenomenon. Informants in this study was determined by purposive method. The purposive sampling technique based on data sources with particular consideration. According to Dolores C. Tongco [10] in a purposive sampling techniques set purposely by researchers. The criteria of the informants is the customers who are exposed to Islamic banks' mudarabah contract be it in funding or financing side from the government banks: Bank Rakyat Indonesia Syariah (BRIS), Bank Syariah Mandiri (BSM), Bank Negara Indonesia (BNIS), Bank Tabungan Negara Syariah (BTNS).The rationale of choosing mudarabah contract is because this contract is the fundamental concept that differentiate between the Islamic and conventional bank.

The banks customers who has a relevant information in this study come from five cities of Indonesia: Surabaya, Sidoarjo, Bojonegoro, Bandung and Tasikmalaya. The information will be triangulated with othe relevant documents from the banks' official website and the banks' annual reports.

The data collection process begins by determining the informant to be met. After the informant is set, then researcher conduct the interviews. The first step is to encounter an open interview informally. This is conducted to multiply informant answers for all questions which have been given, the researcher also wrote the answers obtained. Some of the topics question in this study include the following: a. Customer consideration before using the services at the Islamic bank; $b$. Services (products) they used ; c. Opinions about the interest and profit sharing; $d$. Opinions on the profit sharing ratio of Islamic bank's mudarabah contract; e. Period of the use of services in the Islamic bank.

The interviews with all informants in this research are 20 people from bank customers of BSM bank, BRI Syariah bank, BNI Syariah bank, BTN Syariah bank, and Mumalat bank. The number of informants are limited when is considered that the information reach saturated data. Data saturation is reached when there is enough information to replicate the study [11]. The data then reduced and coded to reveal the phenomenon. The presentation of the findings in the Findings and Discussion section will quote some of the informant which is considered representing the other informants in order not to do repetition.

\section{FINDINGS AND DISCUSSION}

\section{A. Findings}

In relation with the fair profit ratio, the public perception on Islamic financial institutions in Indonesia is still dominated by the opinion that conventional financial institutions are still better than IFI. It is because they are considered cheaper in their price. But not only that; It is assumed that Islamic Bank, where profit sharing is the main distinguishing factor with conventional financial institutions, does not provide a sense of fairness in the distribution of its ratio. The comparison between the profit sharing ratios of Indonesia Islamic banks and the conventional counterpart can be observed at TABLE I.

TABLE I. COMPARISON OF PROFIT SHARING RATIO AND INTEREST RATE

\begin{tabular}{|c|c|c|c|c|c|}
\hline \multicolumn{4}{|c|}{ Profit Sharing Ratio 2017} & \multicolumn{2}{|c|}{$\begin{array}{c}\text { Interest Rate } \\
2017\end{array}$} \\
\hline BSM & $\begin{array}{c}\text { Custo- } \\
\text { mer } \\
(\%)\end{array}$ & $\begin{array}{c}\text { Bank } \\
(\%)\end{array}$ & $\begin{array}{l}\text { EQ. } \\
\text { Rate } \\
(\%)\end{array}$ & $\begin{array}{c}\text { Bank } \\
\text { Mandiri }\end{array}$ & $\begin{array}{r}\text { Rate } \\
(\%)\end{array}$ \\
\hline 1 Month & 50 & 50 & & 1 Month & 4.8 \\
\hline 3 Month & 51 & 49 & & 3 Month & 5.1 \\
\hline 6 Month & 52 & 48 & & 6 Month & 5.8 \\
\hline 12 Month & 53 & 47 & & 12 Month & 5.4 \\
\hline BNIS & $\begin{array}{c}\text { Custo- } \\
\text { mer } \\
(\%) \\
\end{array}$ & $\underset{(\%)}{\text { Bank }}$ & $\begin{array}{l}\text { EQ. } \\
\text { Rate } \\
(\%) \\
\end{array}$ & BNI & $\begin{array}{r}\text { Rate } \\
(\%)\end{array}$ \\
\hline 1 Month & 46 & 54 & 4.69 & 1 Month & 5.6 \\
\hline 3 Month & 47 & 53 & 4.8 & 3 Month & 5.8 \\
\hline 6 Month & 49 & 51 & 5 & 6 Month & 6.3 \\
\hline 12 Month & 50 & 50 & 5.1 & 12 Month & 6.1 \\
\hline BRIS & $\begin{array}{c}\text { Custo- } \\
\text { mer } \\
(\%)\end{array}$ & $\begin{array}{c}\text { Bank } \\
(\%)\end{array}$ & $\begin{array}{l}\text { EQ. } \\
\text { Rate } \\
(\%)\end{array}$ & BRI & $\begin{array}{r}\text { Rate } \\
(\%)\end{array}$ \\
\hline 1 Month & 44 & 56 & 5.1 & 1 Month & 5.1 \\
\hline 3 Month & 45 & 55 & 5.22 & 3 Month & 5.6 \\
\hline 6 Month & 46 & 54 & 5.34 & 6 Month & 5.6 \\
\hline 12 Month & 47 & 53 & 5.46 & 12 Month & 5.6 \\
\hline BRIS & $\begin{array}{c}\text { Custo- } \\
\text { mer } \\
(\%) \\
\end{array}$ & $\underset{(\%)}{\text { Bank }}$ & $\begin{array}{l}\text { EQ. } \\
\text { Rate } \\
(\%) \\
\end{array}$ & BTN & $\begin{array}{r}\text { Rate } \\
(\%)\end{array}$ \\
\hline 1 Month & 40 & 60 & 5.41 & 1 Month & 6.1 \\
\hline 3 Month & 43 & 57 & 5.81 & 3 Month & 6.3 \\
\hline 6 Month & 44 & 56 & 5.95 & 6 Month & 6 \\
\hline 12 Month & 44 & 56 & 5.95 & 12 Month & 5.5 \\
\hline
\end{tabular}

Source: Islamic and conventional banks' counters and websites 
From TABLE I, it can be observed the comparison between the profit sharing ratios of Islamic banks (on the left hand side) and interest rates of conventional banks (on the right hand side) of Indonesia for the year 2017. Regarding the profit sharing ratio each customer has their own opinion. For example Mr. YA, one of the managers of Islamic magazine in Surabaya City, felt the injustice. YA is interested to take financing at IFI. He himself wanted to practice Islamic economy in his life. He is an Islamic Bank customer with a mudaraba contract. Here's a comment of YA related to his experience, "Islamic banks are no better than conventional banks in return. Islamic bank's return is bigger than conventional one. It makes my friends and I prefer to borrow from the conventional because we are able to profit more with the same weight of my business. If IFI doesn't give a fair sense, what is the Islam label for?" [12]

The same experience also conveyed by other customer, $\mathrm{AH}$, a member of religious organization from Sidoarjo City, East Java. He also has the assumption that the profit-sharing ratio offered by the Islamic Bank where he keeps his money is not fair. "How come Islamic Bank is more expensive than conventional banks? The burden that in partaking the business is the same and the profit I get is less. If felt the injustice. Better in conventional banks, " said AH [13]

A customer from Bandung City-West Java Province, named ES felt the same. Mr. ES revealed that the determination of mudarabah contract ratio is still unilateral and seems to be covered up. This means there is no transparency by the bank. Only customers with large funds can bargain just like the counterpart bank. This bargain is also mentioned by the Shariah, however there is a limit that it cannot go beyond the price of conventional banks. "If you go inside the office, no one can speak bluntly on the determination of the ratio. It's company's secret. The one who has the authority to negotiate the price is usually the head of the branch, but it's for the non-routine activity. Just like in a conventional bank when we have we can negotiate with the head but not with operational branch. In Islamic bank, if there is a new big fund then can negotiate. And the result is usually not much different than conventional.'[14]

Customer named IW form Tasikmalaya City, West Java Province, felt no clarity from the start that should be done by the bank. "The report of the profit sharing should not only the numbers but also to which investment is the money invested," said IW [15]. Justice in this case according to IW is on the clarity and transparency on the usage of fund by the bank as capital manager. In this manner, the mudarabah is used in funding by the bank.

The more or less experience felt as well by a customer named RS, who also Islamic economic scholar. He expresses himself as a customer in several Islamic and conventional banks. He has a feeling that it is more or less the same as what has been experienced by other customers who felt the unfairness of the profit sharing ratio. When he was asked whether the profit sharing ratio Bank mudaraba is fair, RS did not answer explicitly, but he immediately highlighted on several aspects such as the first aspect like negotiation that should be given equally to all of the customers. This is because the customer's position is equal to the Bank either as the owner of capital or capital manager. Added to this, there is a tendency that Islamic banks distinguish between prime customers and those not. The prime customers get more facilities in the form of negotiation than the non-prime customers. "My experience in some banks where I became the customer, usually we do not have sufficient authority to change the offer from the bank, in terms of bidding the ratio. The offer is so, we just follow it. But when the customer (rabul maal / mudharib) is prime customer, then it can be negotiated."[16]

Another phenomenon also highlighted by RS is in the vagueness of the mechanism in determining the ratio, even though it is negotiable. In general, Islamic Bank does not provide detailed explanation of the reasons for determining the ratio given. "Actually even when it is negotiated, it is not the percentage of the ratio, but generally is the equivalent rate which is negotiated. Customers usually do not know how much the equivalent rate is. How much is the equivalent rate when it's converted to nisbah. This is what customers do not know. Equivalent rate is not fixed. Usually based on what margin, i.e. 7 percent net, which is normally negotiated. If the 0.7 is the ratio then what is the percentage. That's what customers do not need to know. That should be the one to be negotiated. Because of the difficulty with the ratio, the real number earned is rather difficult to calculate."[16]

From the experience of RS, there is a model of determining the ratio of Islamic Financial Institution that tries to find the equivalent rate expected to be competitive to what is priced by conventional financial institutions. However, the equivalent rate determination model is not disclosed so that the injustice is perceived in the determination of the profit sharing ratio.

\section{B. Discussion}

The profit sharing ratio experienced by YA, AH, ES, IW, $\mathrm{RS}$, and other customers who have the same experience as they are, are the result of the profit sharing ratio by adjusting the ratio to the interest rate of the conventional bank. Moreover, from the above exposition, it is found a phenomena of injustice in terms of ratio determination, especially on mudaraba contract. This become the widely phenomenon occurred in Indonsia Islamic banks, and could be in the Islamic banking world. In addition, the phenomenon raises the curiosity about how the ratio should be determined so that it can meet the sense of justice, especially in Islamic perspective. This is because Islam is a religion that promotes justice. In the Qur'an, it is mentioned that being fair closer to taqwa to Allah SWT. As set forth in Holy Koran in Surah Al Maidah verse 8 [17].

In the current global economic and financial crisis The Islamic bank's products pricing, which include profit sharing ratio, are determined by benchmarking method [18]. Islamic finance has been using conventional finance benchmarks, such as JIBOR, BLR, KLIBOR, COFI, LIBOR, etc, in deciding its own cost of funds (COF), and hence its return to financial investments. In this manner, the conventional pricing becomes the market price. There are two opinions regarding this 
practice. The first opinion says that it is not allowed in fixing the price be it to be lower or higher than the marke price. In case when the market price is regular, a majority of jurists of Hanafites, Malikites, Shafi'ites and Hanbalites disallow the government to fix the prices of products and services. The second opinion says that it is permisible in preserving the basis of justice between people and to avoid injustice (zulm) to the public interest (maslahah ammah). According to the Hanafi and group of Maliki and Shafi' jurists, the government is allowed to fix the market price when there is a price increases above the normal price in the market.[18]

Price benchmark has the intention of controlling the market pricing. This is the effect of a benchmark pricing which is used as guidance and indicator. However, a benchmark for pricing is also in accordance with the maqasid al Shariah (the objectives of Shariah) which is to establish fairness or justice in financial transaction. Ibn Ashur also suggested that using a benchmark would also realizing other maqasid al shariah which are among others [19] transparency (wuduh), preservation and fair circulation of wealth (rawaj) in the hands of as many people possible. Establishing a standard or banchmark would help the government in regulation which is to prevent fraud and manipulation in the market. By this, will creates a healthy market in line with the doctrines in the Shariah.

What the customer felt has its rationale. It is in accordance with the principles of contracts in Islamic Finance which are based on two famous legal maxims in Islamic jurisprudence. This maxim are derived from Hadith of Prophet (s.a.w), i.e., the notion of "al-Kharaj bildaman" and "al-ghunm bilghurm"[20]. The idea of al-kharaj bil-daman explicates that with right to profit tails the ownership responsibilities of damage or loss to the contractual asset. While the idea of alghunm bil-ghurm propose that profits can be obtained only upon assuming accountability of expenses and losses. As such both legal maxims relate profits from trade with assumption of accountability of losses and expenses as well as accountability of damage or loss to the asset contracted. These principles entails one's duty ensures a man to receive a compensatory balancing right.

\section{CONCLUSION}

In this research a phenomenon of injustice experienced by Islamic banks in Indonesia is widely spread. This phenomenon occurred since there are two gaps which is found from this research. First the gap between IFIs and conventional in practice pricing. In this case conventional financial institution has a standard in terms of the determination of interest which is the basis for giving credit so that the fairness question on the interest rate becomes irrelevant. It is because interest rate is in accordance with the standards set by the authorized institution. In addition, there is no order to be fair in a conventional economy which is contrary to practice in Islamic economics.

The other gap is that between the Islamic banks themselves there is no standard. Hence there are various methods in determining the profit sharing ratio of Islamic Banks which come up to different sense of justice between the customers.
However, how to determine the fairness itself every informant still has not given objective answer, because this has never been done before. So far, the stipulated ratios are considered unfair, but due to the current situation and condition necessitates one of the parties to be forced to give in or to be willing by the determination.

The phenomenon of injustice felt by the Islamic banks customers are legitimate since that the practice in the mudarabah contract violates the Islamic jurisprudence which represented in the legal maxim of "al-Kharaj bildaman" and "al-ghunm bil-ghurm."

\section{ACKNOWLEDGMENT}

This work was supported by doctorate research grant from Indonesian Ministry of Research, Technology, and Higher Education (Direktorat Riset dan Pengabdian Masyarakat Direktorat Jenderal Penguatan Riset dan Pengembangan Kementerian Riset, Teknologi, dan Pendidikan Tinggi Republik Indonesia) in 2017.

\section{REFERENCES}

[1] W. Al-Zuhayli, Financial Transactions in Islamic Jurisprudence, vol. 1. Damascus: Dar al-Fikr, 2002.

[2] M. S. Bashir, "Analysis of Customer Satisfaction with the Islamic Banking Sector : Case of Brunei Darussalam," Asian J. Bus. Manag. Sci., vol. 2, no. 10, pp. 38-50, 2012.

[3] S. Begum, "A Comparative Study of Customer Satisfaction of Islamic Banks and Conventional Banks in Oman," SIJ Trans. Ind. Financ. Bus. Manag., vol. 2, no. 4, pp. 207-211, 2014.

[4] M. Khan, "Customer Satisfaction Level of Islamic Bank and Conventional Bank in Pakistan," IOSR J. Bus. Manag., vol. 11, no. 1, pp. 31-40, 2013.

[5] N. Azeem Khattak, "Customer satisfaction and awareness of Islamic banking system in Pakistan," African J. Bus. Manag., vol. 4, no. 5, pp. 662-671, 2010 .

[6] I. Osman, H. Ali, A. Zainuddin, W. E. W. Rashid, and K. Jusoff, "Customers Satisfaction in Malaysian Islamic Banking," Int. J. Econ. Financ., vol. 1, no. 1, pp. 197-202, 2009.

[7] H. Ş. Okumuş, "Interest-free banking in Turkey: A study of customer satisfaction and bank selection criteria," J. Econ. Coop., vol. 26, no. 4, pp. 51-86, 2005.

[8] D. Wulandari and A. Subagio, "Consumer Decision Making in Conventional Banks and Islamic Bank based on Quality of Service Perception," Procedia - Soc. Behav. Sci., vol. 211, no. September, pp. 471-475, 2015.

[9] Lexy J. Moleong, Metode Penelitian Kualitatif. Bandung: Remaja Rosdakarya, 2010.

[10] M. D. C. Tongco, "Purposive Sampling as a Tool for Informant Selection," vol. 5, pp. 147-158, 2007.

[11] M. O'Reilly and N. Parker, “'Unsatisfactory Saturation': a critical exploration of the notion of saturated sample sizes in qualitative research," Qual. Res., vol. 13, no. 2, pp. 190-197, 2013.

[12] Y. Adityawan, "Personal Interview," Unpublished, Surabaya, 2017. 
[13] A. Hidayat, "Personal Interview," Unpublished, Sidoarjo, 2017.

[14] E. Syarief, "Personal Interview," Unpublished, Bandung, 2016.

[15] I. Wisandani, "Personal Interview," Unpublished, Tasikmalaya, 2017.

[16] R. Sukmana, "Personal Interview,” Unpublished, Surabaya, 2017.

[17] A. Y. Ali, "The Meaning of The Noble Qur' an," Commentary, p. $467,2006$.

[18] M. A. Omar, A. M. Noor, and A. K. M. Meera, "Islamic Pricing Benchmark," Int. Shari'ah Res. Acad. Islam. Financ., vol. 1, no. 16, p. $78,2010$.

[19] M. al-T. ibn Ashur, "Treatise on Maqasid al shariah," Book, vol. 1, pp. 1-517, 2006.

[20] B. Saiti and A. Abdullah, "The legal maxims of Islamic law (excluding five leading legal maxims) and their applications in Islamic finance," J. King Abdulaziz Univ. Islam. Econ., vol. 29, no. 2, pp. 139-151, 2016. 